\title{
Pre-history and Origins of the Hero in El libro del cavallero Zifar and Amadís de Gaula*
}

\section{Pre-historia y orígenes del héroe en El libro del cavallero Zifar y Amadís de Gaula}

\author{
Axayácatl Campos García Rojas \\ Universidad Nacional Autónoma de México \\ axa1968@hotmail.com
}

\begin{abstract}
This article studies the concept of pre-history in the heroic and chivalric development of the main characters in El libro del Cavallero Zifar and Amadís de Gaula. In the narrative of this romances, the pre-history refers to the account of significant events prior to the gestation of the hero, and to the previous history of his origins. The analysis of the works and its structure allows us to understand two types of pre-history: One built with remote, mythical and legendary elements, brought to the knight's present life as memories given by his ancestors; and the other given to the reader as part of the narrative and plot of the work; this one results more direct and closer in time.
\end{abstract}

\section{KEYworDs: Pre-history, Hero's Development, Ancestors}

Este artículo se centra en el estudio del concepto de la pre-historia en la configuración y estructura del desarrollo heroico de los caballeros protagonistas de El Libro del Cavallero Zifar y Amadís de Gaula. En la narración caballeresca, la pre-historia se refiere al relato de sucesos significativos previos a la gestación del héroe y a la historia de sus orígenes. A través de los contenidos y la estructura de los ejemplos analizados, se destaca dos tipos de pre-historia: una construida con remotos elementos míticos y legendarios, traídos al presente del caballero como memorias de los ancestros; y la otra que se narra como parte de la misma trama argumental de la obra, donde los acontecimientos son más cercanos y directos.

Palabras Clave: pre-historia, desarrollo heroico, ancestros

ny study of the knight-errant's life obliges us to review the different
events that, since early childhood, affect his path in life. At the outset,
he is confined to a domestic and familiar realm where the homeland

* This article is a revised section of my doctoral thesis (Campos García Rojas, Geography and the Hero's Development). I would like to thank the Universidad Nacional Autónoma de México (FFyL-DGAPA) for the financial support I received from this institution during the time I devoted to this research. 
and childhood represent his world. In medieval Castilian romances, the hero's destiny is affected by the conditions of his birth, the pre-history of his origins, and the education he receives. Since these early moments of his life, the hero-knight is a child like any other human being, but certain special circumstances that surround him leave a deep imprint on his spirit and will remain with him into the future.

It is relatively common to find some descriptions of childhood in the Middle Ages, but this concern becomes specially interesting and significant when the matter is a hero's childhood. ${ }^{1}$ There are abundant episodes in medieval literature, that depict aspects like signs and birthmarks as part of a heroic destiny, or even the details of a hero's pre-weaning period. Also the careful education that he receives at the homeland is of human concern. All this 80 shows that, although implicit, the experiences during early childhood were considered essential for the formation of individual personality during the Middle Ages.

However, the period of time before a hero's birth has been scarcely described, and its weighty influence neglected. The fascinating and marvellous descriptions of a hero's birthmarks, prophecies, and magical events often foreshadow the prelude and pre-history of his origins. This is, therefore, a period of the hero's development that still needs the attention of criticism.

The hero is a special being called to complete an exemplary task that restores the natural order or saves the members of his community; for that reason, his birth is associated with signs that announce his destiny and represent a link between his origins, generally noble, and his heroic future. Gracia Alonso says that "un relato de antepasados refuerza la función que tiene el de la infancia" (Análisis, 398), and, thus, the importance of the origins or the prehistory of the hero.

I shall analyse here the significant events and details of the hero's pre-history and origins before the crucial moment of his birth. For this article, I will use examples from El libro del cavallero Zifar and Amadís de Gaula. Both romances provide with illustrating episodes on their heroes' pre-history and origins. Although I am aware of El libro del cavallero Zifar is not in fact a

\footnotetext{
${ }^{1}$ The studies by Martínez Blanco ("La figura del niño" and "Las edades de la vida") are an important comment on the role of children during the Middle Ages. For the pre-weaning period, see Cacho Blecua ("Nunca quiso mamar lech"); for the subject of birthmarks and signs of heroic destiny and heroes' education, see Gracia Alonso (Análisis, Las señales, "Tradición heroica y eremítica", "El nacimiento de Esplandián”), Delpech ("Du héros marqué au signe du prophète"), and Campos García Rojas ("El simbolismo" and "Las señales y marcas").
} 
proper romance of chivalry, I will analyse it with a comparative approach to the heroic development and its characteristics.

\section{EL LIBRO DEL CAVALLERO ZIFAR}

The hero's origins are those events that happened before his birth; they constitute a pre-history, told and retold, which directs his future life. These past events that are outside his control pertain to his ancestors, parents, relatives, and the situation into which he will be born. So important is the influence of this pre-history that, in El libro del cavallero Zifar the words of Zifar's grandfather, retained in his memory, are the force that inspires him to seek and regain a kingdom lost by his ancestors.

"Amiga señora”, dixo el Cauallero Zifar, "yo seyendo moço pequeño en casa de mi auuelo, oy dezir que oyera a su padre que venia de linaje de reys; e yo commo atreuido pregunte que commo se perdiera aquel linaje, e dixome que por maldad e por malas obras de vn rey del su linaje que fuera despuesto, e que fazieran rey a vn cauallero sinple, pero que era muy buen ome e de buen seso natural e amador de justiçia e conplido de todas buenas costunbres" [... ]. "E sy nos de tan grant logar venimos", dixe, "commo fincamos pobres?” Respondio mi auuelo e dixo que por maldat de aquel rey onde desçendimos, ca por la su maldat nos abaxaron asy commo tu ves" (Wagner, Zifar, 33-34).

This pre-history that makes Zifar's life special, and that was related to him during childhood, makes a deep impression on him and motivates his adventures in search of a kingdom. The ultimate aim of the story is to show that prosperity and the recovery of a kingdom can be obtained only by embracing "buenas costunbres" (Wagner, Zifar, 33). The story, moreover, does not end with the crowning of Zifar as king of Mentón, but goes on to describe the adventures of Roboán, his younger son who, after his own adventures in the external world, also learns "buenas costunbres". He eventually develops in personal, social, and political aspects. The main and final goal in life, then, is a personal achievement within a framework of certain ideal values.

The pre-history of Zifar's origins depicts an ordinary knight who was rewarded with a kingdom to which he was not the heir. This story gives to Zifar the knowledge and ability to recover a kingdom for himself and his family. 
"E sy yo fuere de buenas costunbres", dixe yo, "podria llegar a tan alto logar?" E el me respondio reyendose mucho, e dixome asy: "Amigo pequeño de dias e de buen entendimiento, digote que sy, con la merçed de Dios, si bien te esforçares a ello e non te enojares de fazer bien; ca por bien fazer bien puede omme subir a alto lugar". [...] E estas palabras que mi auuelo me dixo de guisa se fincaron en mi coraçon que propuse entonçe de yr por esta demanda adelante (Wagner, Zifar, 34).

Thus it seems that the promise made in the pre-history might be applicable to every man. In El libro del cavallero Zifar this proposition is of universal significance and could stimulate its public to be successful in life by observing "buenas costunbres". This is what González calls "máxima trayectoria social" (El Cavallero, 118, 127). She says that in political and social terms 82 this represents a behaviour model that could inspire everyone to achieve the maximum, personally or politically, for himself and his family.

Zifar's pre-history is the spark that will ignite his ambition; it will cause him to go out into the external world in order to prove that he deserves a kingdom. It could be argued that success would not be so simple for anyone who did not have Zifar's expectations on account of his noble birth, Yet he had only the word of his grandfather, as, indeed, any grandson might have for the deeds of the distant past (Contreras Martín, "Zifar en busca del linaje"). Zifar believes in the pre-history of his origins, in his ancestral tradition, and he trusts in God. It is not without significance that during the first part of the work, Zifar should be called "El cavallero de Dios". Any doubt that the efficacy of trusting in God is universally applicable and even dispelled by the example of the Ribaldo who, by virtue of his merit, is knighted and named "Cavallero Amigo" (Wagner, Zifar, 190-191), proving that those without noble birth can hope for social advancement within their place in the medieval social and political structure.

Diz ("Estructura" and "La construcción") studies the special characteristics of the origins of Zifar and his successor Roboán. The origin of Zifar is legendary, and it convinces him that he owns a noble and royal lineage. His humiliation at the loss of his noble pedigree is accentuated by the curse inherited from King Tared, which results in the death, after ten days, of any horse he owns (Diz, "Estructura”, 31-33, 39-40). ${ }^{2}$

\footnotetext{
${ }^{2}$ Contreras Martín says that the death of the horses is the result of the curse that hangs over the lineage of Zifar, and that he inherited it because of his ancestor's "malas costunbres". This is a physical and present reminder of an unwished-for and destructive past. The curse will not be cancelled until the knight experiences biological and spiritual evolution. The death of
} 
For Roboán, by contrast, his origins are already enriched by his father's deeds. He is already a prince and this fact obviously opens to him the doors of opportunity:

En el reino de Pandulfa, Seringa formula seis preguntas al infante recién llegado: si es caballero; si es hijo de rey; si es casado; de dónde viene, por qué ha abandonado su tierra; qué quiere ganar. [... ] Por ser hijo de rey, y por mostrar además que posee las cualidades que su origen supone, Roboán es considerado por Seringa como candidato deseable para el trono de Pandulfa (Diz, “La construcción”, 108-09).

The story of his origins is passed from generation to generation, and enriched by the deeds of his ancestors. Thus, El Hijo de Bendición, Roboán's heir, will be the son of emperors and will recall his legendary origins: how a kingdom in India was lost by his ancestors through "malas costunbres", and how his grandfather, Zifar, gained another, Mentón, by the glory of his deeds. And the deeds of his father, Roboán, constitute a pre-history of noble origins which he will pass to posterity. Thus, the story says:

the horses has two meanings: a negative one that impoverishes their owner, and a positive one that "recuerda y pone de manifiesto a Zifar su responsabilidad para con su linaje, siendo en el último extremo el motor de la salida del héroe" ("La muerte de los caballos", 266). Acebrón Ruiz also notes that "la muerte de los caballos de Zifar es el síntoma de un desequilibrio espiritual que obliga al caballero a iniciar su viaje y con él su mejoramiento íntimo" ("Psicomaquia", 807). In the same way, a horse is the transport by which Roboán loses the happiness he had in the Islas Dotadas episode, but it also will bring him to success as emperor of Trigrida. It is also interesting to consider the sexual significance of horses. A horse is commonly found in traditional and contemporary poetry as a representation of human sexuality:

El caballo [... "es un arquetipo muy difundido en la mitología y en el folklore. Como animal representa la psiquis no humana, lo animal, y, por tanto, lo psíquico inconsciente... Por ser inferior al hombre representa al bajo vientre y al mundo de los instintos que suben de él” [Jung 1946]. Caballo y caballero, en un análisis psicológico, forman una sola unidad. (Devoto, "El mal cazador", 490).

From this perspective, the curse on Zifar could be understood as a loss or restriction of his sexual life. The chastity vow that Zifar embraces to avoid committing adultery with the princess of Mentón will be the nadir of this sexual abstinence that the death of the horses announced. The curse will not be cancelled until the knight experiences a biological and spiritual evolution. Only when his spiritual, family, and political life have returned to normality, his sexual life is restored (once he has been reunited with his wife Grima). At this moment Zifar is no more "El cavallero de Dios", but the King of Mentón; he is the best knight and a paterfamiliae. The curse vanishes and the horses cease to be a problem for him. His spiritual life has been tested and he is liberated from sexual abstinence. For the possible origins of King Tared, see Richthofen ("Los crímenes del rey ‘Tared’ histórico”).

Medievalia 50, 2018, pp. 79-93 
[EI Fijo de Bendiçion] çiertamente bendicho fue entre todos los omes deste mundo, ca este fue onrrador de su padre e de su madre, e muy mandado a todas las cosas que aquellos querian, e amador de justiçia con grant piedat, e muy granado en sus dones al que entendia que lo auia mester, de guisa que ninguno en el su señorio non era pobre nin auia ninguna mengua, sy por su grant maldat non fuese. E en quanto este niño ouo syete años, dexaronlo en el inperio. [...] dizen que ay fecho vn libro en caldeo, en que cuenta toda la su vida e muchos buenos fechos que fizo (Wagner, Zifar, 514-516). ${ }^{3}$

In this way the story repeats itself, but the actions constitute a history that will become a pre-history, an ascendant spiral path that represents the evolutionary development of human life. According to Reckert (Beyond Chrysanthemums, 155-156) this spiral is frequently represented in medieval literature and art by towers, mountain-temples, and conical shapes that remind us of the rise of heroes' life.

This quest for a lost origin and for a past age has also, in anthropological terms, strong links with the nostalgia for Paradise that has fascinated humanity since Antiquity. In El libro del cavallero Zifar, the evocation of the origins in Asia (India in this case) gives to the pre-history a character even more remote and exotic, and a place near to the location of the Garden of Eden (Wright, The Geographical Lore, 272-274; O’Gorman, La invención de América, 110111). "E este regno es en la India primera, que poblaron los gentiles, asy commo agora oyredes. [...] e desta Yndia fue el Cauallero Zifar onde fue el rey Tared, que fue ende rey" (Wagner, Zifar, 36).

People in the Middle Ages knew of India's existence and used its name as a common referent for remote places. Although India and Asia appear on medieval maps and in the books of travellers, the familiar way in which they are mentioned does not imply that the speaker was certain of what was to be found there (Wright, The Geographical Lore, 272-278; Harney, "The Geography" and "More on the Geography"). They may be similar to the planets of the solar system today: we know about them but, at the same time, we

\footnotetext{
${ }^{3}$ The legendary book, mentioned here, which records in Chaldean the story of the life and adventures of the Hijo de Bendición, exemplifies the topos of the false translation in Hispanic romances. It is not mentioned that that book had been translated, but it is clear that, as in the Amadis sequels, this resource is used to give to the works, amongst other features, mystery and verisimilitude (Marín Pina, "El tópico de la falsa traducción"). The reference to a book written in a foreign and remote language can be understood as a feature that is added to the pre-history of the knight. Thus, the possible descendants of the Hijo de Bendición, in contrast to Zifar, would have a historical record that would clearly explain their noble origin.
} 
do not know them directly by the experience of have been there. Thus, Asia and India were places that, because of their remoteness and mystery, became suitable locations in an Earthly Paradise, or for the adventures of Zifar's story. To have his origins in India links the hero strongly with exoticism and to the marvels of Orient. These allusions to origins near Paradise make it appropriate that Zifar should be called the knight of God. Diz says that:

A primera vista, tanto la ubicación geográfica como la temporal de las acciones relatadas en el Cifar compartirán con la novela de caballerías el carácter de lejanía en tiempo y en espacio. El protagonista es un caballero de las Indias: no puede imaginarse en la Edad Media, una ubicación geográfica más remota y aún casi fantástica. [... ] La acción de la novela de caballerías ocurre en un tiempo tan remoto del nuestro que resulta intemporal, porque no podemos, ni se nos ocurre, ubicarla, ni siquiera metafóricamente, en ningún tiempo: es el tiempo de la fantasía. El Cifar, en cambio, presenta personajes que se mueven en una intemporalidad cuya naturaleza les permite pertenecer a todos los tiempos ("Estructura", 191).

Furthermore, since the story is located close to the Paradise, the fantastic geography of El libro del cavallero Zifar allows the characters to keep in memory the story of their origins with a remarkable cultural meaning. It is not only the remote geography that makes medieval Castilian romances relevant to any time and place; the actions and values depicted are equally universal.

\section{Amadís DE GAULA}

The pre-history of Amadís's origins, unlike that of Zifar, is not a legend preserved in the memory of his ancestors, but an important part of Rodríguez de Montalvo's narrative. The reason for regarding Zifar's origins as a pre-history is that they are contained only in his grandfather's evocations of the past. Amadís's origins, on the other hand, while dealing with the story of his birth, are part of the narrative itself. Our knowledge of it depends not on one character evoking the past, but on the details given by the omniscient narrator.

Amadís's pre-history has significant features that create a background for the main character, and suits those characteristics of the hero's archetype (Rodríguez de Montalvo, Amadís, 227 n. 4). It is also possible to find the same characteristics in folkloric narrative, like traditional tales. The romance starts by setting the actions in a time and a place: the pre-history of Amadís begins "no muchos años después de la passión de nuestro Redemptor y Salvador 
Jesuchristo [cuando] fue un rey cristiano en la Pequeña Bretaña por nombre llamado Garínter, el cual, seyendo en la ley de la verdad, de mucha devoción y buenas maneras era acompañado” (Rodríguez de Montalvo, Amadís, 227). This early information is significant in the origins of Amadís since it places him at a historically privileged moment for the medieval Christian public and makes him seem familiar (Cacho Blecua, Heroísmo mítico cortesano, 402).

The hero's genealogy is also a detailed description of historical facts, but it is narrated like a traditional folk-tale.

Este Rey [Garínter] ovo dos fijas en una noble dueña su muger, y la mayor fue casada con Languines, Rey de Escocia [... ]. La otra fija, que Helisena fue llamada, en grand cantidad mucho más hermosa que la primera fue. Y comoquiera que de muy grandes príncipes en casamiento demandada fuesse, nunca con ninguno dellos casar le plugo; antes su retraimiento y santa vida dieron causa a que todos beata perdida la llamassen [...] (Rodríguez de Montalvo, Amadís, 227).

This introduction reminds us of the folk-tale of a king with three very different daughters (Bethelheim, Psicoanálisis, 139-145). This similarity between Amadís pre-history and the folk-tale invests him with importance and high birth. In contrast with Zifar, who was born with his origins in a prehistory where the "malas costunbres" caused the ruin of King Tared, Amadís has a honourable and noble past: his grandfather, king Garínter, was "en la ley de la verdad, de mucha devoción y buenas maneras" (Rodríguez de Montalvo, Amadís, 227). His mother, princess Elisena, was not only beautiful, but chaste and devout. These features, undoubtedly, will be passed to Amadís. Love is the feeling that dominates the pre-history of Amadís. This creates a suitable atmosphere for the hero's conception that it will also be present in the faithful love that Amadís will profess for princess Oriana (Cacho Blecua, Heroísmo mítico cortesano, 402).

The episode is also interesting if it is observed from the perspective of a hero who by marrying a princess, in some way defeats or replaces an old king (Frazer, The Golden Bough, II, 269-272; González, El Cavallero, 122-123). This movement in the social structure and the generation hierarchies is a reflection of an anthropological fact that frequently appears in literary works. For example, in El libro del cavallero Zifar the main character becomes king of Mentón by marrying the daughter of the old monarch (Wagner, Zifar, 164-165, 484-485).

King Perión's case is different. His relationship with Princess Elisena corresponds to the conditions of a secret marriage that later will become public (Ruiz de Conde, El amor y el matrimonio secreto). He, therefore, does not 
inherit at that moment a kingdom, since he already rules and owns one. In the case of Perión, Garínter and Elisena, the traditional replacement of the old king does not really occur, bur it is symbolically represented by the conception of Amadís. The knight-king, Perión, left his homeland like Zifar, Roboán and other heroes with a particular goal: the desire to meet king Garínter, who was renowned and prestigious. Perión of Gaula fits the profile of the traditional hero who leaves home in search of an adventure, travels throughout a vast external geography, and finally arrives at another kingdom. In that new kingdom he finds King Garínter, and fortuitously princess Elisena, who will become the centre and origin for his descendant: Amadís. The life of Elisena, who up to this point had been chaste and very religious, is also dramatically changed and disrupted by the arrival of this king. Perión's visit is the spark that ignites her change and leads the narrative to the birth of the future hero.

The meeting of the two kings (Perión and Garínter) is significant. In the first instance they seem to be at the same level in the hierarchy of power: the principal difference between them is only their age. Since he is younger, it is Perión who introduces himself to Garínter by his successful deeds, proving both his courage and his noble origin.

In a forest, Perión is attacked by some knights "muy sobervios y de malas maneras" (Rodríguez de Montalvo, Amadís, 228) who are subjects of king Garínter. Perión kills them, and in this way he shows to Garínter his physical and ethical superiority:

Esto fecho, el cavallero se vino contra el Rey [Garínter], y como solo le viesse díxole: "Buen hombre, ¿qué tierra es ésta que assí son los cavalleros andantes salteados?" El Rey le dixo: "No os maravilléis de esso, cavallero, que assí como en las otras tierras ay buenos cavalleros y malos, assí los ay en ésta, y estos que dezís no solamente a muchos han fecho grandes males y desaguisados, mas ahun al mismo rey su señor, sin que dellos justicia fazer pudiesse: por ser muy enparentados han fecho enormes agravios y también por esta montaña tan espessa donde se acogían” (Rodríguez de Montalvo, Amadís, 228).

In this episode, the motif of hunting is significant. Cacho Blecua (Amadis, 229 n. 15) remarks that the hunting scene in which king Perión takes part is an intrinsic part of folklore. Hunting action in medieval literature symbolizes the love encounter, but normally with the outcomes inverted: success in one leads to failure in the other. Devoto ("El mal cazador") analyses texts where "el mal cazador" and an unsuccessful hunting scene precede the successful encounter between two lovers. But in Perión's case, the hunt is not 
only a success, but it works for the knight-king in showing his skills. King Perión, then, is not only strong and the owner of noble values, but he also has courage and skills in both hunting and love. The pre-history that Amadís inherits is enriched with these hunting scenes, not only by the values passed on by his father, but by all its symbolic significance. ${ }^{4}$

The geographical locations of these hunting scenes and the fight with the knights also have significance in folklore. King Garínter said that he had not been able to bring them to justice, "por esta montaña tan espessa donde se acogían” (Rodríguez de Montalvo, Amadís, 228). The hunting scene takes place in a field away from the village where they were looking for refuge. Forest and Mountain (because of the characteristics of the land and the abundant vegetation) are places far away from civilization and culture, diametrically opposite to cities and courtly life. In such places dangerous events may occur (Le Goff, La civilisation, 170-171; Thiébaux, "An Unpublished" and The Stag of Love; and Rogers, The Perilous Hunt). From this perspective, the virtuous deeds of Perión contrast with the hostile geography in which they are immersed, and this fact underlines his values. Thus, Garínter says gladly about Perión that "No sin causa tiene aquel fama del mejor cavallero del mundo" (Rodríguez de Montalvo, Amadís, 229). This statement is based on his recognition of the values and duties that make up the profile of a good knight.

In the encounter of Perión and Elisena there are features that also create a propitious environment for the conception, and later the birth, of the hero. The lovers meet in a village during a feast. This scene is a moment of pleasure and joy. The banquet has ritual significance, and this one depicts two kings occupying equal positions in the hierarchy. It symbolizes integration into a group, and the implicit establishment of a covenant of peace between both monarchs (Gennep, The Rites of Passage, 20-21, 24, 29).

Esto fecho, recogida toda la compaña, hizo [Garínter] en dos palafrenes cargar el león y el ciervo y llevarlos a la villa con gran plazer. Donde seyendo de tal huesped la Reina avisada, los palacios de grandes y ricos atavíos y las mesas puestas fallaron; en la una más alta se sentaron los Reyes y en otra junto con ella Elisena, su hija, y allí fueron servidos como en casa de tan buen hombre ser devía. Pues estando en aquel solaz, como aquella infanta tan hermosa fuese y el rey Perión por el semejante, y la fama de sus grandes cosas en armas por todas las partes del mundo divulgadas, en tal punto y ora se miraron, que la gran honestidad y santa

\footnotetext{
${ }^{4}$ For the relationship between concepts like love, hunting and war, see Devoto ("El mal cazador", 485-488).
} 
vida della no pudo tanto que de incurable y muy gran amor presa no fuesse, y el Rey assí mismo della, que fasta entonces su coraçón sin ser sojuzgado a otra ninguna libre tenía, de guisa que assí el uno como el otro estuvieron todo el comer cuasi fuera de sentido (Rodríguez de Montalvo, Amadís, 230).

The banquet can also be considered as a ritual of purification, or a passage from an outside world into an intimate one. Perión, who has travelled from one kingdom to another, needs to be incorporated into the new one. This incorporation culminates in his meeting with Elisena and the subsequent conception of Amadís.

"Purifications" (washing, cleaning, etc.) constitute rites of separation from previous surroundings; there follow rites of incorporation (presentation of salt, a shared meal, etc.). The rites of the threshold are therefore not "union" ceremonies, properly speaking, but rites of preparations for union, themselves preceded by rites of preparation for the transitional stage (Gennep, The Rites of Passage, 20-21).

The feast which precedes the love encounter is the stage of transition between the forest and the village-woman. The ritual occurs in a village, and this concept, like that of the city, is strongly linked to the idea of motherhood and fertility (Eliade, Mythes, rêves et mystères, 211, 232-233). It is, thus, significant that Perión finds Elisena in a village, where they love each other and she becomes pregnant of Amadís.

There are some features typical of the courtly love tradition which form the love scenario for Elisena and Perión: love at first sight, secret marriage, premonitory dream, a confidante (a young female character who serves as an accomplice), the interchange of tokens (represented by the ring that Perión gives to the princess, and that eventually will serve to identify the young Amadís), and a locus amoenus (the orchard that Elisena crosses to meet Perión). ${ }^{5}$ All these features surround the pre-history and origins of Amadís, and are undoubtedly embedded in the courtly love tradition, but they are also linked to folklore motifs and rituals of incorporation.

From the analysis of these episodes, and the events occurred before the hero's birth in El libro del cavallero Zifar and Amadís de Gaula it is possible to confirm strong influence of the pre-history and the origins in the knight's

\footnotetext{
${ }^{5}$ For aspects of the love-accomplice characters in medieval Castilian romances, see Beltrán ("Relaciones de complicidad"), and Petruccelli ("Un enfoque semiológico", 233). For the topos of love at first sight see Ynduráin ("Enamorarse de oídas", 597), and Alvar ("Amor de vista, que no de oídas").
}

Medievalia 50, 2018, pp. 79-93 
future life. The very early and previous moments of the knight's existence are strongly related, and devoted, to his heroic destiny. The remote history of $\mathrm{Zi}$ far's ancestors motivates him to search for a kingdom in accordance to his royal lineage. This ancient and almost nostalgic memory of his origins will even be passed down to his descendants. On the other hand, Amadís owns a pre-history endowed with folklore features, and clear characteristics of courtly love that certainly serve as prelude of his future behaviour as knight and faithful lover. It seems that having successful hunting scenes, friendly meetings of his ancestors, and a case of love at first sight, followed by a sexual encounter and secret marriage, ensures an ideal profile for the future hero-knight.

Therefore, it is not only important to pay attention to the conditions of a hero's birth, and his later education. It is equally substantial, for his behaviour 90 and success, the imprint that his pre-history leaves on his conception. The influence of the hero's origins will eventually emerge showing his special place in the world, and his ready prepared spirit for the completion of his quest.

\section{WORKS CITED}

Acebrón Ruiz, Julián, "Psicomaquia: el proceso interior de la aventura en el Libro del Cavallero Zifar", en Ramón Lorenzo (ed.), Actas do XIX Congreso Internacional de Lingüística e Filoloxía Románicas: Universidade de Santiago de Compostela, 1989, t. VII, A Coruña: Fundación "Pedro Barrié de la Maza, Conde de Fenosa”, 1994, 801-810.

Alvar, Carlos, “Amor de vista, que no de oídas”, en Homenaje a A. Zamora Vicente, t. III, Madrid: Castalia, 1991, 13-24.

Beltrán, Rafael, "Relaciones de complicidad ante el juego amoroso: Amadís, Tirant y la Celestina en María Eugenia Lacarra (ed.), Evolución narrativa e ideológica de la literatura caballeresca, Bilbao: Universidad del País Vasco, 1991, 103-126.

Betrelheim, Bruno, Psicoanálisis de los cuentos de hadas, Barcelona: Crítica, 1977. Cacho Blecua, Juan Manuel, Amadís: heroísmo mítico cortesano, Madrid: Cupsa; Zaragoza: Universidad de Zaragoza, 1979.

Cacho Blecua, Juan Manuel, “ 'Nunca quiso mamar lech de mugier rafez': notas sobre la lactancia: del Libro de Alexandre a don Juan Manuel”, en Vicente Beltrán (ed.), Actas del I Congreso de la Asociación Hispánica de Literatura Medieval (Santiago de Compostela diciembre 1985), Barcelona: PPU, 1988, 209-222.

Campos García Rojas, Axayácatr, Geography and the Hero's Development in Three Medieval Castilian Romances, tesis doctoral, London: Queen Mary and Westfield College, University of London, 2000. 
Campos García Rojas, Axayácatl, "El simbolismo del juego de ajedrez en Tristán de Leonís, en Alan Deyermond (ed.), Proceedings of the Tenth Colloquium of the Medieval Hispanic Research Seminar, Papers of the Medieval Hispanic Research Seminar, 30, London: Queen Mary and Westfield College, Department of Hispanic Studies, 2000, 99-113.

Campos García Rojas, Axayácatl, "Las señales y marcas del destino heroico en El libro del cavallero Zifar. Garfín y Roboán”, Bulletin of Hispanic Studies (Liverpool), 78 (January), 2001, 17-25.

Contreras Martín, Antonio M., "El caballero Zifar en busca del linaje”, en Aires A. Nascimento y Cristina Almeida Ribeiro (eds.), Literatura Medieval: Actas do IV Congresso da Associação Hispânica de Literatura Medieval (Lisboa, 1-5 Outubro 1991), t. II, Lisboa: Cosmos, 1993, 155-159.

Contreras Martín, Antonio M., "La muerte de los caballos en el Libro del caballero Zifar, en María Isabel Toro Pascua (ed.), Actas del III Congreso de la Asociación Hispánica de Literatura Medieval (Salamanca, 3 al 6 de octubre de 1989), t. I, Salamanca: Biblioteca Española del Siglo xv y Departamento de Literatura Española e Hispanoamericana, 1994, 261-268.

Delpech, François, "Du héros marqué au signe du prophète: esquisse pour l’archéologie d'un motif chevaleresque”, Bulletin Hispanique, 92, 1990, 237-257.

Devoto, DAniel, "El mal cazador", en Studia philologica: homenaje ofrecido a Dámaso Alonso por sus amigos y discípulos con ocasión de su $60^{\circ}$ aniversario, t. I, Madrid: Gredos, 1960, 481-491.

Diz, Marta Ana, Estructura, género y lección moral del 'Cavallero Cifar', tesis doctoral, University of Maryland, 1976.

Diz, Marta Ana, "La construcción del Cifar", Nueva Revista de Filología Hispánica, 1979, 105-117.

Eliade, Mircea, Mythes, rêves et mystères, Paris: Gallimard, 1957.

Frazer, James G., “The Magic Art and the Evolution of Kings", en The Golden Bough: A Study in Magic and Religion, 2 vols., London: Macmillan, 1920.

Gennep, Arnold VAn, The Rites of Passage: A Classic Study of Cultural Celebrations, trad. de Monika B. Vizedom y Gabrielle L. Caffee, Chicago: UP, 1960.

González, Cristina, "El Cavallero Zifar" y el reino lejano, Madrid: Gredos, 1984.

Gracia Alonso, María Paloma, Análisis y estudio de "Amadís de Gaula" en relación con otras narraciones caballerescas: algunos aspectos, tesis doctoral, Barcelona: Universitat de Barcelona, 1989.

Gracia Alonso, María Paloma, Las señales del destino heroico, Barcelona: Montesinos, 1991.

Gracia Alonso, María Paloma, “Tradición heroica y eremítica en el origen de Esplandián”, Revista de Filología Española, 72, 1992, 133-148.

Medievalia 50, 2018, pp. 79-93 
Pre-history and Origins of the Hero in El libro del cavallero Zifar and Amadís de Gaula

Gracia Alonso, María Paloma, "El nacimiento de Esplandián y el folclore”, en María Isabel Toro Pascua (ed.), Actas del III Congreso de la Asociación Hispánica de Literatura Medieval (Salamanca, 3 al 6 de octubre de 1989), t. I, Salamanca: Biblioteca Española del Siglo xv y Departamento de Literatura Española e Hispanoamericana, 1994, 437-444.

Harney, Michael P., "The Geography of the Caballero Zifar", La Corónica, 11, 1982-1983, 208-219.

Harney, Michael P., "More on the Geography of the Libro del Cavallero Zifar", La Corónica, 16.2, 1988, 76-85.

Le Goff, Jacques, La civilisation de l'Occident médiéval, Paris: Arthaud, 1967.

Marín Pina, María CARmen, "El tópico de la falsa traducción en los libros de caballerías españoles”, en María Isabel Toro Pascua (ed.), Actas del III Congreso de la Asociación Hispánica de Literatura Medieval (Salamanca, 3 al 6 de octubre de 1989), t. 1, Salamanca: Biblioteca Española del Siglo xv y Departamento de Literatura Española e Hispanoamericana, 1994, 541-548.

Martínez Blanco, Carmen María, "La figura del niño en los textos alfonsíes", en José Manuel Lucía Megías, Paloma Gracia Alonso y Carmen Martín Daza (eds.), Actas del II Congreso Internacional de la Asociación Hispánica de Literatura Medieval (Segovia, del 5 al [9] de octubre de 1987), t. II, Alcalá de Henares: Universidad, 1992, 456-469.

Martínez Blanco, Carmen María, "Las edades de la vida: la infancia en la documentación literaria medieval”, en María Isabel Toro Pascua (ed.), Actas del III Congreso de la Asociación Hispánica de Literatura Medieval (Salamanca, 3 al 6 de octubre de 1989), t. I, Salamanca: Biblioteca Española del Siglo Xv y Departamento de Literatura Española e Hispanoamericana, 1994, 563-568.

O'Gorman, Edmundo, La invención de América: investigación acerca de la estructura histórica del nuevo mundo y del sentido de su devenir, México: Fondo de Cultura Económica, 1977.

Petruccelli, María Rosa, “Amadís de Gaula: un enfoque semiológico de los personajes”, en Rosa E. Penna y María A. Rosarossa (eds.), Studia Hispánica Medievalia III: Actas de las IV Jornadas Internacionales de Literatura Española Medieval, Buenos Aires: Universidad Católica Argentina, 1995, 232-236.

Reckert, Stephen, Beyond Chrysanthemums: Perspectives on Poetry East and West, Oxford: Clarendon Press, 1993.

Richthofen, Erich von, “Los crímenes del rey 'Tared' histórico y el origen del nombre de su redentor 'Cifar", en La metamorfosis de la épica medieval, Madrid: Fundación Universitaria Española, 1989, 67-75.

Rodríguez de Montalvo, Garcí, Amadís de Gaula, ed. de Juan Manuel Cacho Blecua, Madrid: Cátedra, 1988-1991. 
Axayácatl Campos García Rojas

Rogers, Edith Randam, The Perilous Hunt: Symbols in Hispanic and European Balladry, Lexington: UP of Kentucky, 1980.

Ruiz de Conde, Justina, El amor y el matrimonio secreto en los libros de caballerías (Zifar, Tirant, Amadís de Gaula, Palmerín de Inglaterra), Madrid: Aguilar, 1948.

Thiébaux, Marcelle, "An Unpublished Allegory of the Hunt of Love: Li dis dou cerf amorous", Studies in Philology, 62, 1965, 531-545.

Thiébaux, Marcelle, The Stag of Love: The Chase in Medieval Literature, Ithaca: Cornell UP, 1974.

El libro del Cauallero Zifar ('El Libro del Cauallero de Dios'): Edited from the Three Extant Versions, ed. de Charles Philip Wagner, Ann Arbor: University of Michigan, 1929.

Wright, John KirTLAnd, The Geographical Lore of the Time of the Crusades: A Study in the History of Medieval Science and Tradition in Western Europe, New York: Dover, 1965.

Ynduráin, Domingo, “Enamorarse de oídas”, en Serta philologica F. Lázaro Carreter natalem diem sexagesimum celebranti dicata, II: Estudios de literatura y crítica textual, Madrid: Cátedra, 1983, 589-603. 
